

\title{
Isolation and characterization of microsatellite markers for Amomum tsaoko (Zingiberaceae), an economically important plant in China
}

\author{
Y.-W. Yang' , Z.-Y. Yang ${ }^{2}$, M.-R. Yan', Z.-G. Qian' ${ }^{1}$ and K.-Y. Guan' \\ ${ }^{1}$ The Center for Reproducing Fine Varieties of Chinese Medicinal Plants, \\ Yunnan College of Traditional Chinese Medicine, Kunming, Yunnan, China \\ ${ }^{2}$ Kunming Institute of Botany, Chinese Academy of Sciences, Kunming, China \\ Corresponding authors: Z.-G. Qian / K.-Y. Guan \\ E-mail: qianzig@yahoo.com.cn / guanky@mail.kib.ac.cn
}

Genet. Mol. Res. 13 (4): 8220-8224 (2014)

Received August 13, 2014

Accepted September 9, 2014

Published October 8, 2014

DOI http://dx.doi.org/10.4238/2014.October.8.3

\begin{abstract}
Twenty-four microsatellite markers were isolated from the genomic DNA of Amomum tsaoko Crevost et Lemaire, an important economic plant in China, using the method fast isolation by AFLP of sequences containing repeats (FIASCO). Polymorphism within each locus was assessed in 60 individuals from three populations in Yunnan Province, China, and nine of them were polymorphic. The number of alleles per polymorphic locus was 2 , and the expected and observed heterozygosities ranged from 0.224 to 0.513 , and from 0.050 to 0.600 , respectively. Among nine microsatellite markers with polymorphism, five showed significant deviation from Hardy-Weinberg equilibrium ( $\mathrm{P}$ $<0.01$ ), probably due to anthropic selection and short-cloning history in cultivation. No significant linkage disequilibrium was detected between loci in our analysis. These polymorphic microsatellite markers will facilitate further studies of gene flow, population structure, identification of cultivated variety, and evaluation of germplasm resources.
\end{abstract}

Key words: Amomum tsaoko; FIASCO; Zingiberaceae; Polymorphism; Genetic structure 


\section{INTRODUCTION}

Amomum tsaoko Crevost et Lemaire is an important member of the ginger family (Zingiberaceae), distributed in Southwest China and Vietnam and found at altitudes ranging from 1300 to 1800 m (Tsai et al., 1981; Tong, 1999; Wu and Larsen, 2000; Xia et al., 2004). As a common traditional Chinese medicine, its fruit is used for the treatment of gastrointestinal fullness and pain, vomiting, and malaria (Chinese Pharmacopoeia Commission, 2010). Owing to its particular fragrance, the fruit is also a favorite food condiment in China. It has been an important crop with significant commercial value, and fruits of some other species in this genus have been found in markets to be mixed with $A$. tsaoko as adulterants.

A. tsaoko has a long history of cultivation in China, especially in southeastern Yunnan Province, but the natural population is rarely found in the wild in recent years (Tsai et al., 1981; Tong, 1998, 1999; Wu and Larsen, 2000). It is proposed that its spatial pattern of genetic diversity should be correlated with anthropic movement and agricultural development, and the quality of fruits should be correlated with the source of seedlings. To infer the origin and migration of cultivated $A$. tsaoko, we need a better understanding of its gene flow and population genetic structure. However, we were not able to obtain polymorphic markers using AFLP, RAPD, or ISSR methods, likely owing to the low diversity in this species, so it was indispensable to develop new markers with high variability. Microsatellite markers (simple sequence repeats, SSRs) are widely used in population genetic analysis and genetic mapping due to the high variability caused by changes in their repeat numbers (Schlötterer and Pemberton, 1998). This paper reports the development of 24 microsatellite markers for $A$. tsaoko to facilitate our further investigations on the correlation between quality of fruits and genetic diversity, identification of cultivated variety, and evaluation of germplasm resources.

\section{MATERIAL AND METHODS}

\section{Isolation of microsatellite loci}

We used the protocol fast isolation by AFLP of sequences containing repeats (FIASCO) to develop microsatellite markers for A. tsaoko (Zane et al., 2002). Total genomic DNA was extracted from silica gel-dried leaves following CTAB methods (Doyle and Doyle, 1987). Approximately $500 \mathrm{ng}$ genomic DNA was digested with MseI restriction enzyme (New England Biolabs, Beverly, MA, USA), and digested fragments were ligated to the MseI adaptor pair (5'-TACTCAGGACTCAT-3'/5'-GACGATGAGTCCTGAG-3') at $37^{\circ} \mathrm{C}$ for $2 \mathrm{~h}$ with T4 DNA ligase (Fermentas, Burlington, Ontario, Canada).

The products were diluted 5-fold and amplified with the primer MseI-N (5'-GATGAG TCCTGAGTAAN-3') according to the following polymerase chain reaction (PCR) program: $95^{\circ} \mathrm{C}$ for $3 \mathrm{~min}$ and 20 cycles of $94^{\circ} \mathrm{C}$ for $30 \mathrm{~s}, 53^{\circ} \mathrm{C}$ for $60 \mathrm{~s}$ and $72^{\circ} \mathrm{C}$ for $60 \mathrm{~s}$, followed by $72^{\circ} \mathrm{C}$ for $8 \mathrm{~min}$. The PCR products with a size range of 200-800 bp were enriched for microsatellite repeats by magnetic bead selection with a 5-biotinylated $(\mathrm{AC})_{15} /(\mathrm{AG})_{15}$ probe. Captured fragments were amplified again with adaptor-specific primers following the abovementioned PCR program (except using 30 cycles), and products were purified using an EZNA Gel Extraction kit (Omega Bio-Tek, Guangzhou, China). The purified PCR products were ligated into the pGEM-T vector (Promega, USA), and transformed into Trans1-T1 Phage Re- 
sistant Chemically Competent Cells (Quanshijin, Beijing, China). Recombinant clones were picked out by blue/white screening, and positive ones were tested by PCR using the primer pairs (AG) ${ }_{10} /(\mathrm{AC})_{10}$ and M13+ (5'-GTAAACGACGGCCAG-3') and (AG) $)_{10} /(\mathrm{AC})_{10}$ and M13(5'-GATGAGTCCTGAGTAAN-3'). The clones with positive inserts were sequenced with an ABI PRISM 3730XL DNA sequencer (Applied Biosystems, Foster City, CA, USA) to design locus-specific primers for those microsatellite sequences with sufficient flanking regions using the program Oligo 6.0 (Offerman and Rychlik, 2003).

\section{Detection of polymorphism}

Polymorphism of these microsatellite loci was assessed among 60 individuals of A. tsaoko from three populations of Yunnan Province, including Baoshan population (20 individuals, $\left.24^{\circ} 50.289^{\prime} \mathrm{N}, 98^{\circ} 46.501^{\prime} \mathrm{E}\right)$, Fadou population (20 individuals, $23^{\circ} 22.326^{\prime} \mathrm{N}$, $\left.104^{\circ} 49.333^{\prime} \mathrm{E}\right)$ and Maguan population (20 individuals, $\left.22^{\circ} 51.631^{\prime} \mathrm{N}, 103^{\circ} 58.802^{\prime} \mathrm{E}\right) . A$. tsaoko planted in one or a few continuous valleys was treated as a population. PCRs were performed in 25-50 ng genomic DNA, $0.5 \mathrm{mM}$ of each dNTP, $0.4 \mu \mathrm{M}$ of each primer, $0.15 \mathrm{U}$ Taq DNA polymerase, and $2.5 \mu \mathrm{L}$ 10X PCR buffer (Takara, Dalian, China). PCR amplification conditions were as follows: 3 min at $93^{\circ} \mathrm{C}$, followed by 33 cycles of $30 \mathrm{~s}$ at $93^{\circ} \mathrm{C}, 30 \mathrm{~s}$ at the optimized annealing temperature (Table 1), and $30 \mathrm{~s}$ at $72^{\circ} \mathrm{C}$, and then a final step for $7 \mathrm{~min}$ at $72^{\circ} \mathrm{C}$. The amplified fragments were sized on $6 \%$ polyacrylamide denaturing gels with a 20-bp ladder molecular size standard (Fermentas) by silver staining.

\section{Data analysis}

Standard genetic analysis of polymorphic loci were performed using POPGENE version 1.32 (Yeh et al., 1997), determining the number of alleles $\left(N_{\mathrm{A}}\right)$, expected $\left(H_{\mathrm{E}}\right)$ and observed $\left(H_{\mathrm{O}}\right)$ heterozygosities, deviation from Hardy-Weinberg equilibrium (HWE), and linkage disequilibrium (LD) between pairs of loci.

\section{RESULTS}

A total of 288 positive clones were selected for sequencing, 265 of which were found to contain SSRs of varying lengths. Sixty sequences with appropriate microsatellites and sufficient flanking regions were selected to design primers, which were screened for amplification and polymorphism using three populations of $A$. tsaoko. Of these, 24 successfully amplified the target regions, and nine of them displayed polymorphisms (Table 1).

Details of polymorphic loci across 60 individuals from the three populations are listed in Table 2. The $N_{\mathrm{A}}$ per locus was 2 , suggesting that perhaps there had been recent bottlenecks for all three populations, that removed the low-frequency alleles, resulting in relatively low diversity, as we found in our early studies using AFLP, RAPD and ISSR methods (Yan M, Yang $\mathrm{Z}$ and Yang $\mathrm{Y}$, unpublished results). $H_{\mathrm{E}}$ and $H_{\mathrm{O}}$ ranged from 0.224 to 0.513 , and from 0.050 to 0.600 , respectively. Tests for HWE and LD were conducted for each of the three populations separately. Among the nine polymorphic loci, five showed significant deviation from HWE (P $<0.01$; Table 2), probably due to anthropic selection and short-cloning history in cultivation. No significant LD was detected between loci $(\mathrm{P}>0.05)$ in our analysis. 
Table 1. Characterization of 24 microsatellite primers for Amomum tsaoko.

\begin{tabular}{|c|c|c|c|c|}
\hline Locus & Primer sequence $\left(5^{\prime}-3^{\prime}\right)$ & Motif & Size (bp) & $\mathrm{Ta}$ \\
\hline At1 & $\begin{array}{l}\text { F-GCTTCACCTCCAGTTTCC } \\
\text { R-GTCCTCCTTGTCCACCC }\end{array}$ & $(\mathrm{GA})_{14}$ & 202 & 59 \\
\hline At3 & $\begin{array}{l}\text { F-GGGATAGGGAGGAGTTTG } \\
\text { R-GGAATTGTGAGCGGATAA }\end{array}$ & $(\mathrm{CT})_{17}$ & 211 & 57 \\
\hline At4 & $\begin{array}{l}\text { F-CTTTACTCTGGTGGATGGA } \\
\text { R-TCATTATTTCACAGCCCTC }\end{array}$ & $(\mathrm{GAA})_{5}$ & 229 & 50 \\
\hline At5 & $\begin{array}{l}\text { F-AATGCAAATGGTGGACG } \\
\text { R-GGATAAATCAAAGAGGAGGA }\end{array}$ & $(\mathrm{GA})_{16}$ & 216 & 58 \\
\hline At6 & $\begin{array}{l}\text { F-TAGGTACAGGTAAGGCAGTT } \\
\text { R-GTTGGCAGGAATTAGGAA }\end{array}$ & $(\mathrm{AC})_{19}$ & 246 & 50 \\
\hline At10 & $\begin{array}{l}\text { F-TTGGCTCTTAGATTTTCCC } \\
\text { R-GGAGCTGTGGCGTTGG }\end{array}$ & $(\mathrm{GT})_{16}$ & 227 & 52 \\
\hline At13 & $\begin{array}{l}\text { F-AGTTTGAGCAATTAGAAGACC } \\
\text { R-TGAAAGATGGAAACAATACAC }\end{array}$ & $(\mathrm{CT})_{19}$ & 173 & 50 \\
\hline At18 & $\begin{array}{l}\text { F-ATTCATTATGCCACTGACG } \\
\text { R-GATGGGCAATTCAAATACAA }\end{array}$ & $(\mathrm{TG})_{14}$ & 222 & 51 \\
\hline At19 & $\begin{array}{l}\text { F-ATTGAGGCCCGACGTC } \\
\text { R-CCAAAGCAAGTGTAACCC }\end{array}$ & $(\mathrm{AC})_{15}$ & 227 & 51 \\
\hline At20 & $\begin{array}{l}\text { F-AGGTCGAGCAGGAGTAGC } \\
\text { R-AGCGGATAACAATTTCACA }\end{array}$ & $(\mathrm{CT})_{17}$ & 256 & 57 \\
\hline At22 & $\begin{array}{l}\text { F-ACCCTTACCTCTTCTCAACA } \\
\text { R-GAGCGGATAACAATTTCAC }\end{array}$ & $(\mathrm{AC})_{17}$ & 304 & 51 \\
\hline At23 & $\begin{array}{l}\text { F-TTGAAGATTTGGAGGTTGT } \\
\text { R-CTCGTGAATGGCTTTGG }\end{array}$ & $(\mathrm{AG})_{16}$ & 286 & 50 \\
\hline At28 & $\begin{array}{l}\text { F-ACTGCGATGTGCTAAAGTT } \\
\text { R-TGATGATTTGGAGGTTGTC }\end{array}$ & $(\mathrm{TC})_{5} \mathrm{~A}(\mathrm{CT})_{22}$ & 271 & 51 \\
\hline At29 & $\begin{array}{l}\text { F-GAGGAGGCGTGGACTTT } \\
\text { R-GGGCTGCTTCTATTTCAT }\end{array}$ & $(\mathrm{GA})_{8}$ & 175 & 58 \\
\hline At30 & $\begin{array}{l}\text { F-TAACGACGAAGGAAACG } \\
\text { R-TGAGTAGGAAAGAAGAAAGAA }\end{array}$ & $(\mathrm{CT})_{9}$ & 184 & 55 \\
\hline At38 & $\begin{array}{l}\text { F-CTCCTTTTCCTTACTTACAGA } \\
\text { R-GATTTTGCCAAACTTGC }\end{array}$ & $(\mathrm{CT})_{22}$ & 195 & 51 \\
\hline At41 & $\begin{array}{l}\text { F-TTAGTTGCTCAGACGAAGTA } \\
\text { R-CTGCAGGTCGACGATT }\end{array}$ & $(\mathrm{CT})_{18}$ & 150 & 51 \\
\hline At42 & $\begin{array}{l}\text { F-ATCCACATCCATCCAGAG } \\
\text { R-CTGCAGGTCGACGATT }\end{array}$ & $(\mathrm{CT})_{19}$ & 144 & 53 \\
\hline At43 & $\begin{array}{l}\text { F-GGTCCTGGTGATTTACTGG } \\
\text { R-CACAAGCTGTCTTTCTTATGTG }\end{array}$ & $(\mathrm{CT})_{27}$ & 137 & 53 \\
\hline At44 & $\begin{array}{l}\text { F-GGTTTGGTTCTTTGTTTTG } \\
\text { R-TACCCGGGGATCCTCTA }\end{array}$ & $(\mathrm{CT})_{17}$ & 153 & 48 \\
\hline At46 & $\begin{array}{l}\text { F-TAGAAACGCAAATGAACAG } \\
\text { R-TGCTGCCATGACCTCCT }\end{array}$ & $(\mathrm{TG})_{11}$ & 102 & 58 \\
\hline At53 & $\begin{array}{l}\text { F-TAACGCCTGGTTTGTGA } \\
\text { R-TTGGAACCTTCGCTTGG }\end{array}$ & $(\mathrm{TG})_{8}$ & 155 & 53 \\
\hline At56 & $\begin{array}{l}\text { F-AGTTTGAACCTCCCATTT } \\
\text { R-ATCTTGAGCTTCGTGCC }\end{array}$ & $(\mathrm{CA})_{6}$ & 177 & 55 \\
\hline At57 & $\begin{array}{l}\text { F-CTGAATCCAACCTCCCA } \\
\text { R-CTCTACCTCTTCTCCTCCAT }\end{array}$ & $(\mathrm{AACCAC})_{3}$ & 156 & 55 \\
\hline
\end{tabular}

$\mathrm{Ta}=$ PCR annealing temperature.

Table 2. Results of initial primer screening in Amomum tsaoko.

\begin{tabular}{|c|c|c|c|c|c|c|c|c|c|}
\hline \multirow[t]{2}{*}{ Locus } & \multicolumn{3}{|c|}{ Baoshan, Yunnan } & \multicolumn{3}{|c|}{ Fadou, Yunnan } & \multicolumn{3}{|c|}{ Maguan, Yunnan } \\
\hline & $N_{\mathrm{A}}$ & $H_{\mathrm{O}}$ & $H_{\mathrm{E}}$ & $N_{\mathrm{A}}$ & $H_{\mathrm{O}}$ & $H_{\mathrm{E}}$ & $N_{\mathrm{A}}$ & $H_{\mathrm{O}}$ & $H_{\mathrm{E}}$ \\
\hline$\overline{\text { At1 }}$ & 2 & 0.400 & 0.492 & 2 & 0.400 & 0.431 & 2 & 0.250 & 0.501 \\
\hline At4 & 2 & 0.350 & 0.409 & 2 & 0.350 & 0.501 & 2 & 0.250 & 0.501 \\
\hline At5 & 2 & 0.250 & 0.409 & 2 & 0.500 & 0.385 & 2 & 0.150 & $0.409^{*}$ \\
\hline At29 & 2 & 0.600 & 0.492 & 2 & 0.500 & 0.513 & 2 & 0.100 & $0.328^{*}$ \\
\hline At30 & 2 & 0.050 & $0.450 *$ & 2 & 0.300 & 0.467 & 2 & 0.250 & 0.450 \\
\hline At46 & 2 & 0.500 & 0.467 & 2 & 0.550 & 0.450 & 2 & 0.450 & 0.481 \\
\hline At53 & 2 & 0.200 & $0.513 *$ & 2 & 0.300 & 0.513 & 2 & 0.200 & $0.513^{*}$ \\
\hline At56 & 2 & 0.350 & 0.358 & 2 & 0.250 & 0.224 & 2 & 0.150 & 0.224 \\
\hline At57 & 2 & 0.350 & 0.512 & 2 & 0.200 & $0.508 *$ & 2 & 0.450 & 0.481 \\
\hline
\end{tabular}

$N_{\mathrm{A}}=$ number of alleles; $H_{\mathrm{E}}=$ expected heterozygosity; $H_{\mathrm{O}}=$ observed heterozygosity. ${ }^{*}$ Statistical deviation from Hardy-Weinberg equilibrium $(\mathrm{P}<0.01)$. 


\section{DISCUSSION}

We developed 9 polymorphic microsatellite markers in A. tsaoko. These loci will be useful for characterizing the population genetic structure of this species. They will be useful molecular markers for further investigation on genetic diversity, mating system and levels of gene flow within and between populations, and will facilitate the determination of the source and commodity quality of $A$. tsaoko.

\section{ACKNOWLEDGMENTS}

Research supported by grants from the Science and Technology Projects of Yunnan Province (\#2009CD078) and the Science Foundation of Yunnan Education Bureau (\#2010Z097).

\section{REFERENCES}

Chinese Pharmacopoeia Commission (2010). Amomum Roxburgh. In: Pharmacopoeia of the People's Republic of China (Chinese Pharmacopoeia Commission, ed.). Vol. 1. Chinese Medicine Science and Technology Press, Beijing, 222223.

Doyle JJ and Doyle JL (1987). A rapid DNA isolation procedure for small quantities of fresh leaf tissue. Phytochem. Bull. 19: $11-15$

Offerman J and Rychlik W (2003). Oligo Primer Analysis Software. In: Introduction to Bioinformatics: A Theoretical and Practical Approach (Krawetz S and Womble D, eds.). Humana Press, Totowa, 345-361.

Schlötterer C and Pemberton J (1998). The Use of Microsatellites for Genetic Analysis of Natural Populations - A Critical Review. In: Molecular Approaches to Ecology and Evolution (Desale R and Schierwater B, eds.). Birkhäuser Verlag, Basel, 71-86.

Tong S (1998). Revision and additional notes of Zingiberaceae of Yunnan, China. Bull. Bot. Res. 18: 137-143.

Tong S (1999). Amomum Roxburgh. In: Flora Yunnanica (Wu Z, ed.). Vol. 8. Science Press, Beijing, 618-639.

Tsai H, Chen P and Zhao S (1981). Amomum Roxburgh. In: Flora Reipublicae Popularis Sinicea (Wu T, ed.). Vol. 16. Science Press, Beijing, 110-135.

Wu T and Larsen K (2000). Amomum Roxburgh. In: Flora of China (Wu Z and Raven P, eds.). Vol. 24. Science Press, Beijing, and Missouri Botanical Garden Press, St. Louis, 347-356.

Xia Y, Kress J and Prince L (2004). Phylogenetic analyses of Amomum (Alpinioideae: Zingiberaceae) using ITS and matK DNA sequence data. Syst. Bot. 29: 334-344.

Yeh FC, Yang R, Boyle TBJ, Ye Z, et al. (1997). POPGENE, The User-Friendly Shareware for Population Genetic Analysis. Molecular Biology and Biotechnology Centre, University of Alberta, Edmonton. Available at [http://www. ualberta.ca/ fyeh/]. Accessed 2013.

Zane L, Bargelloni L and Patarnello T (2002). Strategies for microsatellite isolation: a review. Mol. Ecol. 11: 1-16. 